\title{
TANGGUNG JAWAB KEPALA RUMAH PENYIMPANAN BENDA SITAAN NEGARA (RUPBASAN) DALAM RANGKA PENGELOLAAN BENDA SITAAN NEGARA YANG RUSAK ATAU HILANG \\ (Kajian Pada RUPBASAN Kelas II Cilacap)
}

Oleh: Ari Rahmanto ${ }^{1}$

\begin{abstract}
Home Storage of Confiscated Objects of the State, or abbreviated as RUPBASAN is a place of objects confiscated by the State for the purposes of the judicial process. This is confirmed in article 44 paragraph (1) of the Criminal Procedure Code which reads "State Seized Objects are stored in the State Seized Object Storage House". Not in the slightest in cases of criminal cases of objects or spoils, many countries have been damaged or even disappeared.

This research is a Normative Juridical Research, where the data is secondary data from some literature, rules and primary data from the results of interviews directly to the research location, which is then analyzed with a qualitative approach.

The results of this study indicate that confiscated objects and spoils in Class II Cilacap RUPBASAN until damaged or issued by several factors in the Law on RUPBASAN do not have the authority to manage goods and booty is only a place where there is no authority for auction or destruction goods and goods, the comfort of resources, facilities and infrastructure that are inadequate and complete from the officers. The responsibility of the RUPBASAN head against confiscated objects that are damaged or lost is only limited to goods and goods is located and entrusted to the RUPBASAN, and the owner of the goods can file a lawsuit directly from goods and goods entrusted to RUPBASAN both quality and quality.

Keywords: RUPBASAN, Seized Objects, Accountability
\end{abstract}

\section{ABSTRAK}

Rumah Penyimpanan Benda Sitaan Negara, atau disingkat RUPBASAN adalah tempat benda yang disita oleh Negara untuk keperluan proses peradilan. Hal ini ditegaskan dalam pasal 44 ayat (1) KUHAP yang berbunyi "Benda Sitaan Negara disimpan di dalam Rumah Penyimpanan Benda Sitaan Negara". Tidak sedikit dalam suatu kasus pidana benda sitaan maupun barang rampasan negara banyak yang rusak bahkan hilang.

Penelitian ini adalah penelitian Yuridis Normatif, dimana data yang digunakan merupakan data sekunder dari beberapa literatur, aturan-aturan perundang-undangan dan data primer dari hasil wawancara dan observasi langsung ke lokasi penelitian, yang kemudian dianalisis dengan pendekatan kualitatif.

Hasil penelitian ini menunjukkan bahwa benda sitaan dan barang rampasan yang ada di RUPBASAN Kelas II Cilacap sampai rusak ataupun hilang disebabkan oleh beberapa faktor diantaranya dalam undang-undang tentang RUPBASAN tidak memiliki wewenang mengelola sepenuhnya benda sitaan dan barang rampasan hanya menjadi tempat penitipan tidak ada wewenang untuk pelelangan maupun pemusnahan basan dan baran, kurangnya sumber daya manusia baik dari segi kualitas maupun kuantitas, sarana dan prasarana yang kurang memadai dan kurangnya integritas dari petugas. Pertanggungjawaban Kepala RUPBASAN terhadap benda sitaan yang rusak atau hilang hanya sebatas benda sitaan dan barang rampasan tersebut berada dan dititipkan ke RUPBASAN, dan Pemilik barang dapat mengajukan gugatan secara Perdata apabila benda sitaan dan barang rampasan yang dititipkan ke RUPBASAN mengalami kekurangan baik secara kuantitas maupun kualitasnya.

Kata Kunci : RUPBASAN, Benda Sitaan, Pertanggungjawaban

\footnotetext{
${ }^{1}$ PNS
} 


\section{A. Pendahuluan}

Dalam Undang-Undang Dasar Negara RI Tahun 1945 (selanjutnya disebut UUD 1945) pada Pasal 1 ayat (3) disebutkan bahwa Negara Indonesia adalah negara hukum. Negara Republik Indonesia sebagai negara hukum yang berdasarkan Pancasila dan UndangUndang Dasar Negara Republik Indonesia 1945 bertujuan mewujudkan tata kehidupan negara dan bangsa yang sejahtera, aman, tentram, serta tertib, yang menjamin persamaan kedudukan warga masyarakat dalam hukum dan pemerintahan. Dalam konteks ini, tentu sangat tepat langkah-langkah pemerintah dewasa ini yang dituangkan dalam kebijakan strategi Pembangunan Nasional tahun 2004 - 2009 dengan agenda utama: Peace, Justice Democracy, dan Prosperity antara lain mengagendakan penegakan hukum guna terciptanya Indonesia yang lebih aman, damai, demokratis, dan lebih sejahtera. $^{2}$

Di dalam KUHAP diatur ketentuan tentang tata cara proses pidana dan juga tentang hak dan kewajiban seseorang yang terlibat dalam proses

${ }^{2}$ Markas Besar Kepolisian Negara Republik Indonesia Badan Reserse Kriminal, Fungsi Integratif Pemeliharaan, Pengawasan, Keselamatan dan Keamanan Benda Sitaan Negara sebaga Bukti TP di RUPBASAN untuk Melindungi para Saksi, Korban dan Terdakwa dalam Mendukung Proses Peradilan pada Tingkat Penyidikan, Jakarta tanggal 16 November 2006, Hal. 1 pidana. Proses pidana yang dimaksud adalah dari tahap pemeriksaan tersangka sampai pada tingkat penyidik. Pemeriksaan tersangka merupakan salah satu usaha untuk mengumpulkan bahan pembuktian, yaitu untuk mendapatkan keterangan atau kejelasan tentang terjadinya suatu tindak pidana yang mungkin melibatkan tersangka berikut barang buktinya.

Dari rangkaian suatu proses peradilan yakni tingkat penyidikan, penuntutan dan sampai putusan hakim tentunya disertakan barang bukti yang dipergunakan si terdakwa dalam melakukan suatu tindak melawan hukum. Barang bukti tersebut akan diambil oleh petugas sebagai barang rampasan negara. Agar barang bukti berupa rampasan negara tersebut terjamin keamanan serta keutuhannya diperlukan suatu Institusi khusus untuk menyimpan dan mengamankannya.

Pasal 44 Ayat (1) dan (2) UndangUndang Nomor 8 Tahun 1981 tentang Kitab Undang-Undang Hukum Acara Pidana (KUHAP) menyatakan bahwa Benda Sitaan Negara disimpan dalam Rumah Penyimpanan Benda Sitaan Negara. Penyimpanan benda sitaan tersebut dilaksanakan dengan sebaikbaiknya dan tanggungjawab atasnya ada pada pejabat yang bewenang sesuai dengan tingkat pemeriksaan dalam proses peradilan dan benda tersebut dilarang untuk digunakan oleh siapapun juga. 
Gagasan dasar tentang amanah Undang-Undang untuk membentuk lembaga baru seperti Rumah Penyimpanan Benda Sitaan Negara (RUPBASAN) adalah untuk tetap terpeliharanya benda yang disita dalam satu kesatuan unit. Dengan kebijakan ini akan memudahkan dalam pemeliharaan dan ada pejabat tertentu yang bertanggung jawab terhadap benda sitaan tersebut sehingga dengan pengelolaan dan pemeliharaan oleh RUPBASAN maka kondisi atau keadaan benda sitaan tetap utuh dan sama seperti pada saat benda itu disita. ${ }^{3}$

Keutuhan benda sitaan sangat diperlukan bukan hanya untuk keperluan pembuktian pada proses peradilan sehingga para saksi tetap dengan mudah mengenali benda sitaan tersebut sama seperti pada saat dilakukan tindak pidana. Tetapi di samping itu dengan tetap utuh dan terpeliharanya benda sitaan, dimaksudkan untuk melindungi hak (milik) tersangka, dan terutama sekali hak milik pihak yang menjadi korban tindak pidana maupun pihak lain yang mungkin terkait dengan tindak pidana.

Upaya melindungi hak milik seseorang yang berupa sesuatu benda yang dalam proses penyitaan ini adalah selaras dengan Undang-Undang Republik Indonesia Nomor: 39 Tahun

\footnotetext{
${ }^{3}$ Noor Kolim, 2003, Pengelolaan Benda Sitaan Negara, Departemen Kehakiman dan Hak Asasi Manusia RI Pusat Pendidikn dan Pelatihan Pegawai, Hal. 1
}

1999 tentang Hak Asasi Manusia Pasal 26, 36, dan 37 yang pada pokoknya mencantumkan bahwa harta/benda dan barang milik seseorang berhak mendapatkan perlindungan dan tidak boleh dirampas dengan semenasemena atau secara melawan hukum.

Selama masih dalam proses peradilan benda sitaan harus disimpan dan dipelihara dan dijaga keselamatan dan keamanannya di dalam RUPBASAN. Dengan demikian, maka selama berada di RUPBASAN maka tanggung jawab secara fisik atas benda sitaan tersebut ada di tangan Kepala RUPBASAN. Sedangkan tanggung jawab secara yuridis berada di tangan pejabat yang berwenang sesuai dengan tingkat pemeriksaan dalam proses peradilan.

Berbagai argumen muncul mengapa barang bukti kejahatan belum sepenuhnya dititipkan di RUPBASAN, mulai dari kurangnya gudang/tempat penyimpanan barang, kurangnya biaya perawatan, kurangnya SDM hingga kurangnya sosialisasi tentang RUPBASAN. Hal ini diperparah dengan kurangnya dukungan dari Pemda setempat dalam penyediaan lokasi dikarenakan belum paham betul akan fungsi RUPBASAN. Saat ini ada 63 UPT RUPBASAN di seluruh Indonesia, Provinsi yang belum terbentuk RUPBASAN adalah Sulawesi Barat, RUPBASANyang menggunakan gedung bekas Lembaga Pemasyarakatan 
sebanyak 17, menumpang kepihak lain ( milik PEMDA ) sebanyak delapan(8), menyewa gedung sebanyak satu (1), 54 di antaranya sudah menyimpan basan dan baran walaupun tidak semua penyidik/penuntut umum menitipkan barang buktinya, sembilan (9) di antaranya belum optimal menjalankan fungsinya, dikarenakan belum mempunyai gedung/lahan. Apapun alasannya semestinya instansi terkait, harus tetap berupaya agar meningkatkan pemahamannya sehubungan tugas pokok dan fungsi RUPBASAN.

Sebagaimana diketahui bahwa secara struktural dan organisatoris, RUPBASAN berada di bawah pimpinan Kementerian Hukum dan HAM RI, sebagai salah satu unit Pelaksana Teknis Direktorat Jenderal Pemasyarakatan. Di dalam RUPBASAN disimpan benda sitaan yang diperlukan sebagai barang bukti dalam pemeriksaan baik di tingkat penyidikan, penuntutan, maupun pemeriksaan di sidang pengadilan. Selain itu RUPBASAN juga merupakan tempat menyimpan barang yang dinyatakan dirampas berdasarkan putusan hakim. Sedangkan dalam melaksanakan tugas pokokya, RUPBASAN mempunyai 3 macam fungsi yaitu fungsi penerimaan, fungsi pemeliharaan dan keamanan serta fungsi pengeluaran dan pemusnahan barang sitaan.
Salah satu RUPBASAN yang sudah berfungsi dan berdiri saat ini adalah RUPBASAN Kelas II Cilacap yang wilayahnya mencakup seluruh wilayah kabupaten Cilacap yang merupakan Kabupaten terbesar di Jawa Tengah termasuk wilayah Pulau Nusakambangan hingga yang paling ujung berbatasan dengan Provinsi Jawa Barat yaitu kecamatan Dayeuhluhur.

Berdasarkan paparan tersebut di atas, maka penulis tertarik untuk mengadakan penelitian. Dalam penelitian ini diangkat judul "Tanggungjawab Kepala Rumah Penyimpanan Benda Sitaan Negara (RUPBASAN) dalam Rangka Pengelolaan Benda Sitaan Negara Yang Rusak Atau Hilang (Kajian Pada RUPBASAN Kelas II Cilacap)".

\section{B. Metode Penelitian}

Pendekatan Normatif adalah pendekatan yang menelaah hukum sebagai kaidah yang dianggap sesuai dengan penelitian yuridis normatif atau penelitian hukum tertulis atau penelitian hukum yang doktrinal, yang bekerja untuk menemukan jawaban-jawaban yang benar dengan pembuktian kebenaran yang dicari dari preskripsipreskripsi hukum yang tertulis di kitabkitab undang-undang. Dengan singkatnya bahwa penelitian yuridis normatif membahas doktrin-doktrin atau asas-asas dalam ilmu hukum. ${ }^{4}$ Dalam

\footnotetext{
${ }^{4}$ H. Zainuddin Ali, 2011, Metode Penelitian Hukum, Sinar Grafika, Jakarta, Hal. 25
} 
penelitian ini peneliti langsung mencari data ke lokasi penelitian dengan mengumpulkan data-data yang sudah ada dari laporan-laporan bulanan maupun data dari dokumen-dokumen yang ada di RUPBASAN Kelas ॥ Cilacap.

Sumber data primer yaitu data yang penulis peroleh melalui penelitian di lapangan yang dilakukan dengan observasi dan wawancara dengan pihak terkait. ${ }^{5}$ Pihak yang terkait penelitian ini antara lain: Kepala RUPBASAN Cilacap, petugas RUPBASAN Cilacap. Data sekunder merupakan data yang diperoleh secara normatif melalui perantara berupa data dan informasi yang terdapat dalam Undang-Undang, Peraturan Perundang-Undangan, bukubuku literatur, hasil penelitian terdahulu, artikel-artikel dan sebagainya yang dilakukan dengan teknik studi pustaka sebagai referensi untuk mendapatkan data dan informasi yang dibutuhkan. Metode Pengumpulan Data tidak lain dari suatu proses pengadaan data primer untuk keperluan penelitian, ${ }^{6}$ yang terdiri dari wawancara (Interview) ${ }^{7}$, Observasi, Dokumentasi yaitu sekumpulan berkas yakni mencari data

${ }^{5}$ Petter Mahmud Marzuki, 2005, Penelitian Hukum;Edisi Revisi, Kencana Prenada Media Group, Jakarta, Hal. 181

${ }^{6}$ Moh Nazir, 2013, Metode Penelitian, GHal.ia Indonesia, Bogor, Hal. 174

7 Sugiono, 2009, Metode Penelitian Pendidikan;Pendekatan

Kuantitatif,Kualitatif, dan $R \& D$, Alfabeta, Bandung, Hal.. 194 mengenai hal-hal berupa catatan, transkrip, buku, surat kabar, majalah, prasasti, notulen, agenda dan sebagainya $^{8}$, Studi Kepustakaan. Metode analisis kualitatif adalah suatu tata cara penelitian yang menghasilkan data deskriptif analitis, yaitu apa yang dinyatakan oleh responden secara tertulis atau lisan, dan juga perilakunya yang nyata, yang diteliti, dan dipelajari sebagai sesuatu yang utuh. ${ }^{9}$

\section{Hasil Penelitian dan Pembahasan}

\section{Hasil Penelitian}

\section{a. Data Primer}

1) Keadaan Bangunan

\section{RUPBASAN Kelas II Cilacap}

Bangunan Rupbasan Kelas

IICilacap berbentuk segi panjang, dan bagian tengah kosong, sebagai halaman dan juga digunakan sebagai penyimpanan mobil berjumlah 4 dengan kondisi terbuka tanpa atap. Sarana gedung yang ada di Rupbasan Kelas II Cilacap, sebagai berikut :

a) 2 unit gudang tertutup

b) 1 unit gudang terbuka

c) 1 unit gudang berharga

d) 1 unit gudang berbahaya

e) 1 unit Ruang Karupbasan

f) 3 unit Ruang Kantor

\footnotetext{
${ }^{8}$ Margono S. Drs. 2007. Metologi Penelitian Pendidikan Komponen MKDK. PT. Rineka Cipta, Jakarta, Hal. 202

${ }^{9}$ Soerjono Soekanto, 2010, Pengantar Penelitian Hukum, UI-Press, Jakarta, Hal. 250
} 
g) 1 unit Ruang Arsip

h) 2 unit Toilet

i) 1 unit Lapangan Upacara

j) 1 unit Tempat Parkir Sepeda Motor

k) 2 unit Rumah dinas

\section{2) Keadaan Pegawai}

Jumlah pegawai sampai saat ini bulan Mei 2018, kantor RUPBASAN Kelas II Cilacap hanya berjumlah 14 pegawai yang terdiri dari:

a) Satu orang Kepala RUPBASAN;

b) Satu orang Kepala Sub Seksi Administrasi dan Pengelolaan;

c) Enam orang Staf administrasi dan pengelolaan;

d) Enam orang petugas penjagaan, dibagi tiga regu, dalam satu regu terdiri dari dua orang petugas.

\section{a. Data Sekunder}

Peraturan perundang-undangan yang menjadi dasar hukum keberadaan RUPBASAN tersebut antara lain sebagai berikut:

1). Undang-Undang Nomor 8 Tahun 1981 tentang KUHAP

Dalam undang-undang ini ada tiga pasal yang memuat materi tentang RUPBASAN, yaitu:

a) Pasal 44 ayat (1) dan (2)

(1) ayat (1) pasal ini memeuat ketentuan bahwa benda sitaan harus disimpan dalam rumah penyimpanan benda sitaan negara. Dari ketentuan pasal inilah dikenal nama lembaga baru "RUPBASAN", yang merupakan singkatan rumah penyimpanan benda sitaan negara.

(1) Ayat (2) pasal ini memuat ide dasar bagaimana cara menyimpan, pejabat mana yang bertanggung jawab secara yuridis. Ayat ini juga memuat larangan pemakaian/penggunaa $\mathrm{n}$ benda sitaan secara tidak sah.

b) Pasal 45 terdiri dari ayat (1) sampai dengan ayat (4)

Pasal 45 ini memuat ketentuan yang berupa perlunya tindakan tertentu jika karena sesuatu hal benda sitaan tidak mungkin disimpan di RUPBASAN, maka benda sitaan dapat dilelang, uang hasil penjual lelang dijadikan sbagai barang bukti. Namun benda sitaan tersebut harus disisakan sebagian kecil untuk keperluan pembuktian.

2) Peraturan Pemerintah Nomor 27 Tahun 1983 tentang Pelaksanaan KUHAP

Dalam Peraturan Pemerintah (PP) Nomor 27 Tahun 1983 ini terdapat sebelas pasal yang memuat materi mengenai RUPBASAN. PP ini merupakan penjabaran empat pasal dari Undang-undang Nomor 8 Tahun 1981 tentang KUHAP. Kesebelas pasal tersebut adalah pasal 1 (point 3-4); 26; 27; 28; 29; 30; 31; 32; 33; 34; dan 39. 
3) Peraturan Menteri Hukum dan HAM RI Nomor 16 Tahun 2014 tentangPengelolaan Benda Sitaan dan Barang Rampasan Negara pada RUPBASAN.

Dalam bab I Peraturan Menteri Hukum dan HAM ini dimuat tentang ketentuan umum RUPBASAN, tempan penyimpanan Basan diluar RUPBASAN, Basan dan Baran, Pengelolaan administrasi, Pengelolaan fisik Basan dan Baran, Tim Peneliti, Petugas Peneliti, pada bab II dijelaskan terkait penerimaan, registrasi, pengklasifikasian, dan penempatan Basan dan Baran, pemeliharaan dan pengamanan, bab III diatur mengenai pengelolaan Basan dan Baran dari penyimpanan, pengamanan, pemeliharaan dan penyelamatan, bab IV tentang jangka waktu pengelolaan, bab $\mathrm{V}$ tentang penggunaan Basan, bab VI cara dan prosedur Pemutasian, bab VII cara dan prosedur Penghapusan, bab VIII cara dan prosedur Pengeluaran, bab IX cara dan prosedur Pelaporan, bab $\mathrm{X}$ cara dan prosedur ketentuan peralihan, terakhir bab XI ketentuan penutup berlaku setelah 6 (enam) bulan terhitung sejak tanggal diundangkan.

4) Keputusan Menteri Kehakiman Nomor M.04-PR.07.03 Tahun 1985 tentang Organisasi dan Tata Kerja RUPBASAN

Keputusan menteri ini memuat tentang kedudukan, tugas pokok, fungsi, klasifikasi dan susunan organisasi RUPBASAN.

5) Petunjuk Pelaksanaan dan Petujuk Teknis Direktur Jenderal Pemasyarakatan Nomor E2.UM.01.06 Tahun 1986 tentang Pengelolaan BendaSitaan dan Barang Rampasan Negara

Juklak-juknis Direktur Jenderal Pemasyarakatan ini yang telah memberi acuan dan petunjuk teknis pengaturan dan pengurusan benda sitaan negara mulai dari penerimaan sampai dengan pengeluaran benda sitaan. Juklak-juknis Direktur Jenderal Pemasyarakatan Nomor E2.UM.01.06 Tahun 1986 ini kemudian disempurnakan dengan Juklak-juknis Direktur Jenderal Pemasyarakatan Nomor E1.35.PK.03.10 Tahun 2002 tentang pengelolaan benda sitaan dan barang rampasan negara dan terakhir disempurnakan dengan 
Keputusan Direktur Jenderal Pemasyarakatan Nomor PAS140.PK.02.01 Tahun 2015 Tentang Juklak-Juknis tentang pengelolaan benda sitaan dan barang rampasan negara di RUPBASAN.

6) Undang-undang Nomor 39 Tahun 2001 tentang Hak Asasi Manusia

Dalam undang-undang ini yang erat kaitannya dengan materi RUPBASAN adalah Pasal 36 dan Pasal 37 yang mencantumkan tentang perlindungan harta/hak milik seseorang (yang sedang dikenakan penyitaan oleh yang berwenang).

\section{PEMBAHASAN}

\section{a. Penyebab Benda Sitaan Sampai} Mengalami Kerusakan Atau Kehilangan Di RUPBASAN Kelas II Cilacap

Di RUPBASAN sebagai tempat penyimpanan benda sitaan dan barang rampasan negara. Kata Benda sitaan terdiri dari dua kata yakni 'benda' dan 'sitaan'. Apa yang dimaksud dengan 'benda' tersimpul dari ketentuan Pasal 499 Kitab Undang- Undang Hukum Perdata yang menyatakan bahwa "Menurut paham undang- undang yang dinamakan kebendaan ialah tiap-tiap barang dan tiap-tiap hak yang dapat dikuasai oleh hak milik".. Istilah 'benda' mempunyai cakupan yang sangat luas. Disamping istilah benda (zaak), didalamnya terdapat istilah barang (goed) dan hak (recht), juga tidak saja meliputi benda berwujud tapi juga benda tidak berwujud. ${ }^{10}$ Sedangkan istilah 'sitaan' dapat diartikan sebagai hasil 'sita' atau hasil dari upaya penyitaan yang dilakukan dalam proses penyidikan. Karenanya, dari pengertianpengertian diatas diatas dapat dijabarkan bahwa yang dimaksud dengan benda sitaan negara adalah benda bergerak atau tidak bergerak, berwujud atau tidak berwujud yang diambil alih dan disimpan dibawah penguasaan penyidik yang selanjutnya akan dipergunakan untuk pembuktian dalam proses penyidikan, penuntutan dan peradilan. ${ }^{11}$

Dalam ketentuan Pasal 499 Burgerlijk Wetboek ( Kitab UndangUndang Hukum Petrdata), kebendaan adalah tiap-tiap barang dan tiap-tiap hak yang dapat dikuasai oleh hak milik, sedangkan dalam ilmu hukum, pengertian benda lebih luas, yaitu segala sesuatu yang dapat menjadi obyek hukum dan barangbarang yang dapat menjadi milik

${ }^{10}$ Frieda Husni Hasbullah, 2002, Hukum Kebendaan Perdata : Hak-Hak yang Memberi Kenikmatan Jilid 1, Cet.II , HilCo,Jakarta, Hal.19

${ }^{11}$ Noor Kolim, Op.cit, Hal. 5. 
$\begin{array}{lrr}\text { serta hak setiap orang yang } \\ \text { dilindungi } & \text { oleh } & \text { hukum. } \\ & { }^{2}\end{array}$

Benda Sitaan Negara (BASAN)

adalah benda bergerak atau tidak bergerak, berwujud atau tidak berwujud yang diambil alih dan disimpan di bawah penguasaan penyidik yang selanjutnya akan dipergunakan untuk pembuktian dalam proses penyidikan, penuntutan, dan peradilan. ${ }^{13}$

Barang Rampasan (BARAN) adalah barang bukti yang telah memperoleh kekuatan hukum tetap, dirampas untuk negara yang selanjutnya dieksekusi dengan cara:(a) dimusnahkan, yaitu: (1) dibakar sampai habis, (2) ditenggelamkan ke dasar laut sehingga tidak bisa diambil lagi, (3) dikubur di dalam tanah, (4) dirusakkan sampai tidak dapat dipergunakan lagi; (b) dilelang untuk negara; (c) disimpan di Rupbasan untuk barang bukti dalam perkara lain. ${ }^{14}$

Benda rusak di RUPBASAN mengacu pada keadaan bahwa benda tersebut sudah tidak sesuai dengan benda saat pertama kali

${ }^{12}$ P.N.H. Simanjuntak, 2009, Pokok-Pokok Hukum Perdata Indonesia, Djambatan, Jakarta, Hal.203

${ }^{13}$ Noor Kolim, 2003, Op.cit, Hal. 7

${ }^{14}$ Suryadarma, Anak Agung Anom, 2007, Sekilas Catatan Pengelolaan Benda Sitaan Negara dan Barang Rampasan Negara di RUPBASAN, makalah, Denpasar 4 Juli 2007, Hal.3 -5 disimpan di RUPBASAN.

Ketidakutuhan benda tersebut dapat diamati, baik dari segi mutu dan jumlah benda sitaan negara. Sedangkan benda hilang mengacu pada lenyapnya benda sitaan sebagian atau seluruhnya. Untuk itu, Kepala RUPBASAN dan petugas terkait perlu memperhatikan Peraturan Menteri Hukum dan HAM RI Nomor: 16 Tahun 2014 Tentang Tata Cara Pengelolaan Benda Sitaan Negara Dan Barang Rampasan Negara Pada Rumah Penyimpanan Benda Sitaan Negara.

Dari hasil penelitian ditemukan banyak sekali benda-benda yang rusak atau dalam kondisi setengah baik, setelah melakukan observasi dengan mengecek data dan langsung melakukan pengamatan ternyata benda-benda dengan kondisi setengah baik tersebut juga mengalami kerusakan fisik, misalnya mobil dalam laporan ditemukan kondisi setengah baik ternyata setelah dicek kondisi ban sudah sempes semua dan dilaporan juga dengan kondisi mesin mati. Sedangkan kondisi rusak misalnya motor kondisinya sudah tidak dapat digunakan lagi dan keadaan sangat parah karena sudah bekas kecelakaan dan sudah terlalu lama disimpan di RUPBASAN.

Friedman membagi sistem hukum menjadi tiga bagian yaitu: 
struktur hukum (legal structure), substansi hukum (legal substance), dan budaya hukum (legal culture). ${ }^{15}$ Struktur hukum adalah komponen struktural atau organ yang bergerak didalam suatu mekanisme, baik dalam membuat peraturan, maupun dalam menerapkan atau melaksanakan peraturan. Substansi hukum adalah produk dari struktur hukum, baik peraturan yang dibuat melalui mekanisme struktur formal atau peraturan yang lahir dari kebiasaan. Sedangkan budaya hukum adalah nilai, pemikiran, serta harapan atas kaedah atau norma dalam kehidupan sosial masyarakat. Kendala yang dihadapi dalam Pengelolaan Benda Sitaan dan Barang Rampasan Negara dalam melaksanakan tugasnya sebagai pengelola benda sitaan dan barang rampasan negara, RUPBASAN dihadapkan pada berbagai kendala di antaranya: dari segi Substansi, Struktur dan Cultur atau Budaya.

Kendala Substansi meliputi peraturan perundang-undangan yang berkaitan dengan pengelolaan benda sitaan dan barang rampasan negara. Belum adanya peraturan bersama tentang kesepakatan atau kesepahaman tentang pengelolaan benda sitaan dan barang rampasan

${ }^{15}$ Lawrence M. Friedman, 2009, Sistem Hukum ; Perspektif Ilmu Sosial (The Legal System ; A Social Science Perspective), Nusa Media, Bandung, Hal. 33 karena ini juga menyangkut barang bukti tindak pidana. Di Kepolisian, Kejaksaan dan KPK ada aturan tersendiri yang berbeda dengan di RUPBASAN.

Dengan adanya perbedaan dan tidak ada undang-undang yang secara tegas untuk mengatur pengelolaan benda sitaan negara sehingga tidak ada tumpang tindih kewenangan maka pengelolaan benda sitaan dan barang rampasan negara belum berjalan maksimal, apalagi RUPBASAN sebagai instansi yang pasif tidak dapat memaksaan penitipan di RUPBASAN dari instansi lain. Kalau di RUPBASAN kondisinya sudah rusak parah dan tidak dapat melakukan tindakan pelelangan maupun pemusnahan sehingga benda sitaan dan barang rampasan tersebut sampai rusak parah karena sudah bertahun-tahun berada di RUPBASAN tanpa ada status kejelasan dari aparat penegak hukum yang lain.

Kendala Struktur Hukum, dalam hal ini berbagai macam kendala yang berasal dari aparat penegak hukum itu sendiri baik yang dari organisasi, sarana prasarana, biaya dan sumber daya manusianya lebih luas lagi peran institusi lain dalam membangun RUPBASAN sesuai dengan ketentuan peraturan perundang-undangan. 
1411 | Jurna I Id ea H u k u m

Vol. $5 \mathrm{No} .2$ oktober 2019

Magister IIm u Hukum Universitas jenderal Soedirman

1) Masih rendahnya sumber daya manusia pegawai untuk melakukan tugas pengelolaan benda sitaan dan barang rampasan negara termasuk kendala secara internal. Kendala yang lain adalah adanya kualitas dan kuantitas pegawai yang belum memadai apabila dilihat dari sifat dan tugas yang dibebankan kepada pegawai RUPBASAN.

2) Terbatasnya sarana dan prasarana serta biaya, juga merupakan kendala internal.

3) Kurangnya koordinasi antara aparat penegak hukum dengan RUPBASAN juga mengakibatkan kondisi seperti itu.

4) Struktur Organisasi RUPBASAN yang kecil setingkat eselon 4 padahal memiliki kewenangan dan tanggungjawab sangat besar jika sesuai dengan ketentuan peratuaran perundangundangan, hal ini menyebabkan seseorang yang mau berkarir di RUPBASAN bisa terhambat sehingga bukan menjadi prioritas utama bagi jajaran pemasyarakatan.
Kendala budaya hukum terkait dengan budaya dalam masyarakat maupun budaya dari aparat itu sendiri. Dalam hal ini masyarakat sebagai korban merasa malu bila ingin mengambil barang bukti seperti korban perkosaan atau korban pelecehan seksusal karena yang menjadi benda sitaan adalah pakaian mereka sehingga dibiarkan saja menumpuk di RUPBASAN, selain itu benda sitaannya sudah rusak karena kecelakaan dan mau mengurus dikejaksaan susah dengan proses yang lama sehingga dibiarkan terbengkalai di RUPBASAN. Budaya hukum petugas juga harus memiliki integritas tinggi dan juga kejujuran sehingga tidak terjadi penyalahgunaan wewenang dalam hal pengelolaan benda sitaan dan rampasan negara. Termasuk juga setiap instansi seharusnya melaporkan benda sitaan ke kepala RUPBASAN setempat jika berada di wilayahnya.

Adanya benda sitaan dan rampasan yang ada di RUPBASAN Kelas II Cilacap sampai hilang disebabkan karena ulah oknum petugas sendiri, hal ini terjadi karena kurangnya rasa tanggung jawab, integritas dan nilai-nilai moral yang kurang sehingga saat mendapatkan tugas untuk menjaga benda sitaan dan barang rampasan agar tidak 
hilang malah melakukannya ketika kondisi sepi dan pada malam hari, berarti kurangnya kejujuran dan menyalahgunakan wewenang untuk mementingkan dirinya sendiri sehingga kasus seperti itu pernah terjadi.

\section{Pertanggungjawaban Kepala}

Rupbasan Terhadap Benda Sitaan yang Rusak Atau Hilang Di RUPBASAN Kelas II Cilacap

Bentuk-Bentuk

Pertanggungjawaban yang harus dapat dilaksanakan sesuai dengan keadaan bagaimana benda sitaan dan barang rampasan sampai rusak dan hilang diantaranya: Pertanggungjawaban Perdata, Pertanggungjawaban Administrasi dan Pertanggungjawaban Pidana.

Di dalam konteks perdata, pertanggungjawaban perdata merupakan tindakan, biasanya dalam bentuk pembayaran ganti kerugian, yang harus dilakukan oleh seseorang atau pihak yang karena perbuatannya telah menimbulkan kerugian pada orang lain. Salah satu ukuran yang digunakan untuk menentukan pertanggungjawaban perdata ini adalah Perbuatan Melawan Hukum.

Di Indonesia untuk mengatakan bahwa seseorang telah melakukan Perbuatan Melawan Hukum, merujuk pada Pasal 1365 KuhPerdata, pasal ini menyatakan bahwa perbuatan orang tersebut haruslah memenuhi unsur-unsur berikut ini: ${ }^{16}$
a. Sifat melanggar hukumnya suatu perbuatan (onrechtmatigheid)
b. Kesalahan (schuld)
c. Kerugian (schade)
d. Hubungan sebab- akibat (causal verband)
e. Relativiteit

Secara teoritis, para ahli menyatakan bahwa prinsip yang digunakan pada pasal 1365 KUHPer tersebut adalah liability based on fault dengan beban pembuktian berada pada penderita (pengguggat). Dalam hal ini, si penderita baru akan memperoleh ganti kerugian apabila ia berhasil membuktikan bahwa si pelaku (tergugat) telah bersalah melakukan perbuatan melawan hukum. ${ }^{17}$ Kesalahan dengan demikian merupakan unsur yang menentukan pertanggungjawaban, sebab bila terbukti terdapat adanya kesalahan dan menerbitkan kerugian maka pihak tergugat wajib untuk mengganti kerugian, dan apabila kesalahan tidak terbukti maka pihak tergugat bebas dari

16 Paulus Effendi Lotulung, 2003 “ Penegakan Hukum Lingkungan oleh Hakim Perdata", Bandung: P.T Citra Aditya Bakti,

${ }^{17}$ Koesnadi Hardjasoemantri, 2005, Hukum Tata Lingkungan, Edisi kedelapan Cetakan kedelapan belas, Gadjah Mada University Press, Yogyakarta, Hal.411 
pertanggungjawaban.
Pengawasan administratif
menurut Suwoto Mulyo Sudarmo
bertujuan untuk mengukur efisiensi
kerja. ${ }^{18}$ Pengawasan administratif
dalam bentuk lainnya adalah
pengawasan administratif yang
bercorak kebijakan (politik). Terkait
dengan persoalan ini ambillah
sebagai contoh suatu bentuk
keputusan administrasi yang dikelompokkan sebagai peraturan kebijakan. Peraturan kebijakan merupakan ketentuan yang dibuat oleh administrasi negara untuk menjalankan suatu kebijakan. Keputusan itu tidak diberi bentuk perundang-undangan karena pejabat administrasi yang bersangkutan memang tidak memiliki kewenangan membentuk perundang-undangan untuk persoalan tersebut. ${ }^{19}$

\section{Peraturan}

kebijakan

disandarkan pada asas kebebasan bertindak yang lazim disebut freies ermessen. Peraturan kebijakan ditujukan hanya pada dua kemungkinan, pertama, kepada pejabat administrasi yang mengeluarkan kebijakan itu sendiri. Kedua, pada badan/pejabat administrasi negara lainnya.

${ }^{18}$ Ibid.,

${ }^{19}$ Dian Bakti Setiawan, 2011,

Pemberhentian Kepala Daerah (Mekanisme

Pemberhentiannya Menurut Sistem

PemerintahandiIndonesia),

PT.RAJAGRAFINDO, Jakarta, Hal. 73
Peraturan kebijakan tidak pernah ditujukan kepada umum. Tetapi karena dikeluarkan dalam rangka penyelenggaraan kepentingan umum maka peraturan kebijakan tersbut tetap menimbulkan akibat tidak langsung bagi masyarakat umum. ${ }^{20}$

Seperti yang telah diuraikan diatas bahwa peraturan kebijakan itu bukan perundang-undangan, dan dibuat tidak atas dasar suatu perundang-undangan melainkan atas dasar kebebasan pemerintah (freies ermessen). Karena itu, penilaian terhadap peraturan kebijakan berbeda dengan penilain terhadap peraturan perundang- undangan. Asas-asas pembuatan dan pengajuan peraturan perundangundangan tidak berlaku terhadap peraturan kebijakan. Pengujian peraturan kebijakan lebih bersifat doelmatigheid. Sebab yang diuji adalah persoalan bijaksana tidaknya pemerintah pada waktu menetapkan peraturan kebijakan yang bersangkutan. Karena itu yang berhak menguji pada dasarnya adalah administrasi negara itu sendiri. Dengan kata lain pengawasannya bersifat adminitratif, dan itu berarti pertanggungjawaban dari pejabat administrasi negara yang bersangkutan

merupakan

${ }^{20}$ Ibid., Hal. 74. 
pertanggungjawaban administratif. ${ }^{21}$

Pertanggungjawaban Pidana

Sistem pertanggungjawaban pidana dalam hukum pidana positif saat ini menganut asas kesalahan sebagai salah satu asas disamping asas legalitas. Pertanggungjawaban pidana merupakan bentuk perbuatan dari pelaku tindak pidana terhadap kesalahan yang dilakukannya. Dengan demikian, terjadinya pertanggungjawaban pidana karena ada kesalahan yang merupakan tindak pidana yang dilakukan oleh seseorang, dan telah ada aturan yang mengatur tindak pidana tersebut. Roeslan Saleh menyatakan bahwa: "Dalam membicarakan tentang pertanggungjawaban pidana, tidaklah dapat dilepaskan dari satu dua aspek yang harus dilihat dengan pandangan-pandangan falsafah. Satu diantaranya adalah keadilan, sehingga pembicaraan tentang pertanggungjawaban pidana akan memberikan kontur yang lebih jelas. Pertanggungjawaban pidana sebagai soal hukum pidana terjalin dengan keadilan sebagai soal filsafat". ${ }^{22}$

$$
\text { Pertanggungjawaban pidana }
$$
menjurus kepada pemidanaan petindak, jika telah melakukan suatu tindak pidana dan memenuhi unsurunsurnya yang telah ditentukan

21 Ibid.

${ }^{22}$ Roeslan Saleh, 2002, Pikiran-pikiran Tentang Pertanggungjawaban Pidana. Ghalia Indonesia. Jakarta. Hal. 10 dalam undang-undang. Dilihat dari sudut terjadinya satu tindakan yang terlarang (diharuskan), seseorang akan dipertanggungjawabkan atas tindakan-tindakan tersebut apabila tindakan tersebut bersifat melawan hukum (dan tidak ada peniadaan sifat melawan hukum atau rechtsvaardigingsgrond atau alasan pembenar) untuk orang itu dilihat dari sudut kemampuan bertanggungjawab maka hanya seseorang yang mampu bertanggung jawab yang dapat dipertanggungjawabkan pidana kan. $^{23}$

Pertanggungjawaban pidana adalah suatu perbuatan yang tercela oleh masyarakat yang harus dipertanggungjawabkan pada si pembuatnya atas perbuatan yang dilakukan. Dengan mempertanggung jawabkan perbuatan yang tercela itu pada si pembuatnya, apakah si pembuatnya juga dicela ataukah si pembuatnya tidak dicela. Pada hal yang pertama maka si pembuatnya tentu dipidana, sedangkan dalam hal yang kedua si pembuatnya tentu tidak dipidana. ${ }^{24}$

Kesalahan dalam arti seluasluasnya, dapat disamakan dengan pengertian pertangungjawaban dalam hukum pidana. Didalamnya

\footnotetext{
${ }^{23}$ E.Y.Kanter \& S.R Sianturi, 2002 Asasasas Hukum Pidana di Indonesia dan Penerapannya. Storia Grafika, Jakarta, Hal. 249

${ }^{24}$ Ruslan Saleh, Op.Cit., Hal. 75-76
} 
terkandung makna dapat dicelanya si pembuat atas perbuatannya. Jadi, apabila dikatakan bahwa orang itu bersalah melakukan sesuatu tindak pidana, maka itu berarti bahwa ia dapat dicela atas perbuatanya. ${ }^{25}$

Unsur-unsur Dalam

Pertanggungjawaban Pidana

Seseorang atau pelaku tindak pidana tidak akan dimintai pertanggungjawaban pidana atau dijatuhi pidana apabila tidak melakukan perbuatan pidana dan perbuatan pidana tersebut haruslah melawan hukum, namun meskipun dia melakukan perbuatan pidana, tidaklah selalu dia dapat dipidana. Orang yang melakukan perbuatan pidana hanya akan dipidana apabila dia terbukti secara sah dan meyakinkan melakukan kesalahan.

Menurut Ruslan Saleh, tidaklah ada gunanya untuk mempertanggungjawabkan terdakwa atas perbuatannya apabila perbuatannya itu sendiri tidak bersifat melawan hukum, maka lebih lanjut dapat pula dikatakan bahwa terlebih dahulu harus ada kepastian tentang adanya perbuatan pidana, dan kemudian semua unsurunsur kesalahan harus dihubungkan pula dengan perbuatan pidana yang dilakukan, sehingga untuk adanya

${ }^{25}$ Tri Andrisman, 2009, Asas-Asas dan Aturan Umum Hukum Pidana Indonesia, Universitas Lampung, Bandar Lampung, Hal. 95 kesalahan yang mengakibatkan dipidanannya terdakwa maka terdakwa haruslah : $:^{26}$

a. Melakukan perbuatan pidana;

b. Mampu bertanggung jawab;

c. Dengan kesengajaan atau kealpaan, dan

d. Tidak adanya alasan pemaaf.

Berdasarkan uraian tersebut diatas, jika ke empat unsur tersebut diatas ada maka orang yang bersangkutan atau pelaku tindak pidana dimaksud dapat dinyatakan mempunyai pertanggungjawaban pidana, sehingga ia dapat dipidana. Orang yang dapat dituntut dimuka pengadilan dan dijatuhi pidana, haruslah melakukan tidak pidana dengan kesalahan.

Kesalahan dapat dibedakan menjadi 3 (tiga) yaitu:

a.Kemampuan bertanggungjawab;

b. Sengaja (dolus/opzet) dan lalai (culpa/alpa);

c. Tidak ada alasan pemaaf. ${ }^{27}$

Dengan menghubungkan petindak dengan tindakannya dalam rangka mempertanggungjawab mempidanakan petindak atas tindakannya, supaya dapat ditentukan pemidanaan kepada petindak harus diteliti dan dibuktikan bahwa :

a. subjek harus sesuai dengan perumusan undang-undang;

b. terdapat kesalahan pada petindak;

\footnotetext{
${ }^{26}$ Ibid, Hal. 75-76

${ }^{27}$ Tri Andrisman, Op.Cit., Hal. 91
} 
c. tindakan itu bersifat melawan hukum;

d. tindakan itu dilarang dan diancam dengan pidana oleh Undang - Undang (dalam arti luas); dan

e. dilakukannya tindakan itu sesuai dengan tempat, waktu dan keadaan lainnya yang ditentukan dalam undang undang. ${ }^{28}$

Menurut Mulyatno (dalam Tri Andrisman $^{29} \quad$ unsur-unsur pertanggungjawaban pidana adalah:

a. Kesalahan;

b. Kemampuan bertanggungjawab;

c. Tidak ada alasan pemaaf.

Moeljatno menyimpulkan bahwa untuk adanya kemampuan bertanggung jawab harus ada:

a. Kemampuan untuk membedabedakan antara perbuatan yang baik dan yang buruk; sesuai dengan hukum dan yang melawan hukum; (faktor akal)

b. Kemampuan untuk menentukan kehendaknya menurut keinsyafan tentang baik dan buruknya perbuatan tadi. (faktor perasaan/kehendak). ${ }^{30}$

Pertanggungjawaban Pidana dapat dilakukan kepada Kepala RUPBASAN jika telah memenuhi unsur-unsur pidana yang sudah

\footnotetext{
${ }^{28}$ Ibid, Hal. 73

29 E.Y. Kanter dan S.R Sianturi. op.Cit., Hal. 253

30

http://syarifblackdolphin.wordpress.com/201 2/01/11/pertanggungjawaban-pidanal diakses pada tanggal 22 Juli 2018
}

diatur dalam undang-undang, dan perbuatan tersebut sudah terumuskan di dalam peraturan perundang-undangan yang berlaku. Hal ini bisa terjadi jika ada pihak yang melaporkan tentang kasus tindak pidana yang dilakukan.

Tata

cara mempertanggungjawabkan basan dan barang yang rusak atau hilang meliputi subjek-subjek dalam gugatan ganti kerugian, secara teori dalam mengajukan gugatan ganti kerugian terhadap barang sitaan yang rusak atau hilang dapat digugat berdasarkan atas adanya perbuatan melanggar hukum. Baik melalui peradilan dan gugatan perdata berdasarkan pada ketentuan pasal 1365 KUHA Perdata.

Subjek-subjek dalam tuntutan ganti kerugian atas barang sitaan pada sistem peradilan di Indonesia antara lain: 1) pihak penggugat dan 2) pihak tergugat. Pihak penggugat adalah pemilik barang (saksi korban) sebagai penggugat I dan tersangka sebagai penggugat II. Pihak tergugat, adalah penyidik sebagai tergugat I, RUPBASAN sebagai tergugat II, dan Penuntut Umum sebagai tergugat II.

Dalam penelitian ini, meskipun subjek tergugat termasuk juga pihak kejaksaan, namun karena pembahasan masalah hanya pada saat barang sudah diserahterimakan di RUPBASAN, maka yang 
ditekankan menjadi pihak tergugat adalah pihak RUPBASAN.

Sedangkan berbicara mengenai subjek yang menjadi pihak penggugat, bila statusnya masih menjadi seorang tersangka maka orang tersebut hanya dapat menuntut ganti kerugian atas barang yang telah disita, ternyata hilang dan rusak melalui proses peradilan. Bagi orang atau sekelompok orang yang ingin mengajukan ganti kerugian melalui proses gugatan perdata, maka yang menjadi subjek penggugat di sini adalah pemilik barang atau saksi korban dan tersangka apabila penyidikannya telah dihentikan sehingga statusnya tidak lagi menjadi seorang tersangka.

Menyusun dan mengajukan gugatan ganti kerugian, dalam perkara perdata inisiatif berperkara datang dari pihak yang merasa dirugikan. Dalam hal ini yang mengajukan gugatan adalah pemilik barang yang barangnya telah rusak atau hilang, di mana yang mengajukan gugatan disebut sebagai penggugat, sedangkan yang digugat dalam hal ini pihak RUPBASAN disebut sebagai tergugat. Ada pun cara mengajukan gugatan dapat dibedakan atas dua jenis, yakni:

a. Permohonan gugatan yang diajukan secara lisan apabila penggugat menulis b. Permohonan gugatan yang diajukan secara tertulis yang disebut dengan surat gugatan.

Ada tiga hal yang mesti diperhatikan dan terdapat dalam surat gugatan yaitu:

a. Keterangan lengkap dari pihakpihak yang berperkara yaitu tentang nama, alamat, umur, pekerjaan, dan agama.

b. Dasar gugatan (fundamentum petendi) yang memuat uraian tentang kejadian-kejadian (feitlijkegronden caftual) hak dalam hubungan hukum yang menjadi dasar yuridis dari gugatan itu.

c. Apa yang domohonkan atau dituntut oleh penggugat supaya diputuskan oleh hakim (petitumpetition), yang dituntut itu dapat diperinci menjadi dua macam yaitu: tuntutan primer yang merupakan tuntutan pokok dan tuntutan subsider yang merupakan tuntutan pengganti apabila tuntutan pokok ditolak oleh hakim. ${ }^{31}$

Dalam surat gugatan ganti kerugian atas rusak atau hilangnya barang sitaan, yang digugat adalah pihak RUPBASAN yang menyimpan barang tersebut. Sedangkan yang menggugat adalah pihak yang memiliki barang sitaan.

Adapun alasan atau dasar gugatan menggugat adalah karena barang yang disita telah rusak atau hilang sehingga menimbulkan kerugian bagi pemiliknya, sedangkan

31 Abdulkadir Muhamad, 2000, Hukum Acara Perdata Indonesia, PT.Citra Aditya Bakti, Bandung, Hal. 56 
barang tersebut seharusnya menjadi tanggung jawab bagi RUPBASAN agar tidak rusak atau hilang selama dalam penyitaan dan apabila barang tersebut kemudian rusak atau hilang, maka RUPBASAN telah melalaikan atau tidak bertanggung jawab akan tugasnya dan atas kelalaiannya itu Kepala RUPBASAN patut digugat. Karena Kepala RUPBASAN bertanggungjawab secara fisik agar barang yang ada di RUPBASAN tetap utuh tidak hilang ataupun rusak. Materi permohonan dalam surat gugatan ganti kerugian tersebut adalah pengembalian barang sitaan dalam bentuk semula atau sejumlah uang sesuai dengan perincian berapa biaya yang digunakan untuk memperbaiki barang sitaan yang rusak atau berapa besar harga barang sitaan yang hilang tersebut (sebesar akibat kerusakan barangbarang yang dijadikan barang sitaan).

\section{Simpulan dan Saran}

\section{Simpulan}

Berdasarkan paparan di atas, dapat ditarik benang merah sebagai simpulan dari penelitian ini yakni:

\section{a. Benda sitaan dan barang rampasan negara sampai ada yang rusak atau hilang, di RUPBASAN Kelas II Cilacap disebabkan oleh:}

1) Rusak disebabkan: a) Karena sudah lama berada di RUPBASAN

b) Tidak adanya aturan yang mengatur RUPBASAN dapat melalukan pelelangan atau memaksa kejaksaan untuk melakukan pelelangan karena kondisi benda sitaan dan rampasan sudah lama dan makin rusak

c) Petugas yang minim, tidak ada tenaga ahli untuk menaksir dan merawat benda sitaan tersebut

d) Sarana prasarana dan anggaran di RUPBASAN Kelas II Cilacap yang minim atau kurang.

2) Hilang disebabkan karena adanya oknum yang mengambil guna kepentinngan pribadinya hal ini berarti kurangnya integritas dan moral dalam diri oknum tersebut.

b. Pertanggungjawaban Kepala RUPBASAN terhadap benda sitaan yang rusak atau hilang yakni:

1) Pertanggungjawaban Perdata dalam bentuk pembayaran ganti kerugian atau dengan penggantian barang baru sesuai dengan gugatan pihak yang dirugikan,

2) Pertanggungjawaban

Administrasi antara lain, a) 
teguran lisan dan tertulis, b) pemutasian, c) pemotongan gaji, d) penundaan pangkat, e) pemberhentian jabatan,

3) Pertanggungjawaban Pidana, apabila dalam pengelolaan basan dan baran terjadi penyalahgunaan wewenang dan memenuhi unsur-unsur pidana maka dapat dipertanggungjawabkan secara pidana sesuai dengan peraturan perundang-undangan yang berlaku.

\section{Saran}

Berdasarkan simpulan tersebut di atas dapat diajukan beberapa saran terkait hasil penelitian ini, antara lain:

1. Pemerintah hendaknya menyediakan sarana dan prasarana yang memadai terkait pengelolaan benda sitaan negara maupun barang rampasan negara, RUPBASAN tidak hanya dijadikan tempat penitipan barang dari instansi lain tetapi hendaknya RUPBASAN dapat menjadi institusi yang dapat mengelola aset negara berupa barang sitaan maupun barang rampasan negara.

2. Pemerintah juga diharapkan dapat meningkatkan kualitas dan kuantitas sumber daya

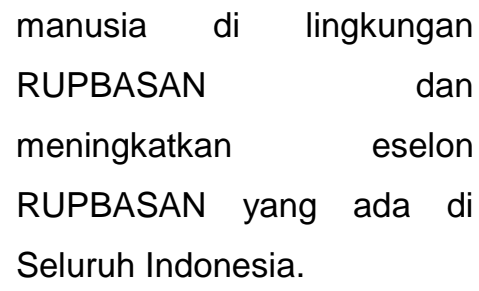

\section{DAFTAR PUSTAKA}

Abdulkadir, Muhamad, 2000, Hukum Acara Perdata Indonesia, PT.Citra Aditya Bakti, Bandung.

Ali, H. Zainuddin, 2011, Metode Penelitian Hukum, Sinar Grafika, Jakarta.

Andrisman, Tri, 2009, Asas-Asas dan Aturan Umum Hukum Pidana Indonesia, Universitas Lampung, Bandar Lampung.

Friedman, Lawrence M., 2009, Sistem Hukum ; Perspektif IImu Sosial (The Legal System ; A Social Science Perspective), Nusa Media , Bandung.

Hardjasoemantri, Koesnadi 2005, Hukum Tata Lingkungan, Edisi kedelapan Cetakan kedelapan belas, Gadjah Mada University Press, Yogyakarta.

Hasbullah, Frieda Husni, 2002, Hukum Kebendaan Perdata : Hak-Hak yang Memberi Kenikmatan Jilid 1, Cet.II , Hil-Co, Jakarta.

Kanter, E.Y., \& S.R Sianturi, 2002 Asasasas Hukum Pidana di Indonesia dan Penerapannya. Storia Grafika, Jakarta.

Kolim, Noor, 2003, Pengelolaan Benda Sitaan Negara, Buku Materi Kuliah Akademi IImu Pemasyarakatan, Jakarta.

Lotulung, Paulus Effendi 2003 “ Penegakan Hukum Lingkungan oleh Hakim Perdata", , Bandung: P.T Citra Aditya Bakti.

Margono, 2007, Metologi Penelitian Pendidikan Komponen MKDK, PT. Rineka Cipta, Jakarta.

Marzuki, Petter Mahmud 2005, Penelitian Hukum;Edisi Revisi, Kencana Prenada Media Group, Jakarta

Nazir, Moh, 2013, Metode Penelitian, Ghalia Indonesia, Bogor. 
ND, Mukti Fajar, Dkk, 2010, Dualisme Penelitian Hukum Normatif Dan Empiris, Pustaka Pelajar, Yogyakarta.

Saleh, Roeslan, 2002, Pikiran-pikiran Tentang Pertanggungjawaban Pidana, Ghalia Indonesia, Jakarta.

Setiawan, Dian Bakti 2011, Pemberhentian Kepala Daerah (Mekanisme Pemberhentiannya Menurut Sistem Pemerintahan di Indonesia), PT.RAJAGRAFINDO, Jakarta.

Simanjuntak, P.N.H. 2009, Pokok-Pokok Hukum Perdata Indonesia, Djambatan, Jakarta.

Soekanto, Soejono 2006, Penelitian Hukum Normatif; Suatu Tinjauan Singkat, Rajawali Pers, Jakarta.

2010, Pengantar Penelitian

Hukum, UI-Press, Jakarta.

Sugiono, 2009, Metode Penelitian Pendidikan;Pendekatan

Kuantitatif,Kualitatif, dan R\&D, Alfabeta, Bandung

Suryadarma, Anak Agung Anom, 2007, Sekilas Catatan Pengelolaan Benda Sitaan Negara dan Barang Rampasan Negara di RUPBASAN, makalah, Denpasar .

Markas Besar Kepolisian Negara Republik Indonesia Badan Reserse Kriminal, 2006, Fungsi Integratif Pemeliharaan, Pengawasan, Keselamatan dan Keamanan Benda Sitaan Negara sebaga Bukti TP di RUPBASAN untuk Melindungi para Saksi, Korban dan Terdakwa dalam Mendukung Proses Peradilan pada Tingkat Penyidikan, Jakarta

SK Dirjen Pemasyarakatan, Nomor: E1.35.PK.03.10 Tahun 2002 tentang Julak dan Juknis Benda Sitaan Negara dan Barang Rampasan Negra di Rumah Penyimpnan BarangSitaan Negara

https://kompas.id/baca/nusantara/2018/0 2/21/gedung-juang-45-cilacapterbakar-puluhan-motor-sitaanhangus/, diakses pada tanggal 3 Mei 2018

$\underline{\text { http://smslap.ditjenpas.go.id/public/rbs/c }}$ urrent/monthly/kanwil/db5f3920- 6bd1-1bd1-b847-

313134333039/year/2018/month/5 , diakses pada 3 Juni 2018

http://syarifblackdolphin.wordpress.com/ 2012/01/11/pertanggungjawabanpidana/ diakses pada tanggal 22 Juli 2018 